\title{
THE AGE OF THE BODLEIAN SYRIAC CODEX
}

\section{$D A W K I N S 3$.}

IN the Catalogue of the Syriac MSS in the Bodleian Library this MS is described as 'saeculi noni, valde vetustus.' Mr. Burkitt in his note On the Gospel pinnara found in Syriac $M S S^{1}$ expresses his assent to opinions I had quoted in Studia Biblica ii, that the MS is much older than the ninth century. He thinks, indeed, that it cannot have been written later than A.D. $55^{\circ}$.

A century ago this codex was carefully collated by Richard Jones, of Wadham '. By a comparison of the handwriting with a specimen of the hand of the Vatican Tetraeuangelium of A.D. 548, he came to the conclusion that the Bodleian MS was either of the same century, or, at latest, of the seventh. Philip Pusey, who collated the greater part of the codex, has not recorded his opinion of its age, though he noted the unsatisfactory character of the text, which he found to be disfigured by mistakes of various kinds to a far greater extent than other MSS he had collated. As I was able to make use of the two collations, by Pusey and by $R$. Jones, I have not had occasion to devote much attention to the MS itself, but from my first inspection of it $I$ inclined to an earlier date than that given in the Catalogue ${ }^{3}$. A recent careful examination has, I think, removed all doubt. At my request, Mr. Cowley had photographs of the writing taken, and these, with the assistance of Mr. G. Margoliouth, were compared with pages of a number of Syriac MSS in the British Museum, some dated, others of acknowledged antiquity. Our unanimous decision was in confirmation of Mr. Burkitt's opinion, which he had formed independently. Mr. Cowley was inclined to go a little further, and ascribe the MS to the beginning of the sixth century, in which case it will rival the antiquity of the Phillipps Tetraeuangelium 4. A facsimile of this MS, which is now in the possession of the Royal Library, Berlin, is given in Sachau's Catalogue of the Syriac MSS in that Library. It is there ascribed to $\mathrm{v}$-vi cent. The hand is certainly finer and better than that of Dazek. 3, but I am not prepared to say that there is much difference between them in point of antiquity.

It would be interesting to know where Dawk. 3 was copied, exhibiting, as it does, so many errors and unsupported readings. In the present defective state of the codex, colophons are wanting. The

1 Journal of Theological Studies ii, April igor, p. 43 I.

2 Textus Euangelorum iuxta Edit. Schaaf. collatus c. duo. codd. MSS Bodl. ed. R. Jones, Oxon. 1805.

'It is cod. 36 in Tetraenangelium Sanctum ed. Pusey et Gwilliam.

- Pusey and Gwilliam's cod. 4 r. 
imperfections of the text are not evidence against the early date; they may even be links of connexion with a period anterior to the time when the art of copying Peshitto MSS had reached the perfection displayed in the dated copies of the sixth century. The addition of the Canons and Harmonies does not imply a later period. 'It is true that, with the exception of the Phillipps MS, these accessories to the text are not found in copies of a date much earlier than A.D. $55^{\circ}$; but then these copies are very few in number, and there is no reason why the system should not have been in use before the close of the fifth century.

It is hard to believe that 'saeculi noni' expresses Dr. Payne Smith's real opinion. I would suggest that he wrote ' 6 th cent.' in his first rough notes. This, in transcription, might easily become 'gth cent.,' and produce, in the Latin of the printed description, an error which, after the manner of its kind, came to stay. But however that may be, Oxford men may have the satisfaction of believing that the Bodleian possesses one of the oldest Syriac Biblical MSS in existence, and they will thank a distinguished member of the sister University for an opinion which has led to examination and correction of an erroneous date.

G. H. Gwilliam. 